\begin{tabular}{|l|l|l|}
\hline \multicolumn{2}{|c|}{ PublisherInfo } \\
\hline \hline PublisherName & $:$ & BioMed Central \\
\hline \hline PublisherLocation & $:$ & London \\
\hline \hline PublisherImprintName & $:$ & BioMed Central \\
\hline \hline
\end{tabular}

\title{
BAG-1 can predict survival from breast cancer
}

\begin{tabular}{|l|l|l||}
\hline \multicolumn{2}{|c|}{ ArticleInfo } \\
\hline \hline ArticleID & $:$ & 4003 \\
\hline \hline ArticleDOI & $:$ & $10.1186 /$ gb-spotlight-20010308-01 \\
\hline \hline ArticleCitationID & $:$ & spotlight-20010308-01 \\
\hline \hline ArticleSequenceNumber & $:$ & 74 \\
\hline \hline ArticleCategory & $:$ & Research news \\
\hline ArticleFirstPage & $:$ & 1 \\
\hline \hline ArticleLastPage & $:$ & 2 \\
\hline \hline & $:$ & RegistrationDate : 2001-03-08 \\
ArticleHistory & $:$ & OnlineDate \\
\hline \hline ArticleCopyright & $:$ & BioMed Central Ltd2001-03-08 \\
\hline \hline ArticleGrants & $:$ & \\
\hline \hline ArticleContext & $:$ & 130592211 \\
\hline \hline
\end{tabular}




\section{Tudor Toma}

Email: ttoma@mail.dntis.ro

Measuring tumour levels of the protein BAG-1 can predict which women with localised breast cancer are at greatest risk of metastases, according to a paper in the February Journal of Clinical Oncology. Bruce Turner, from Thomas Jefferson Universityin Philadelphia, and colleagues studied 122 women with early stage breast cancer. They analysed paraffin blocks of excised tumors and found that cytosolic immunostaining for BAG-1 - a protein that inhibits apoptosis - was greater in 79 of 122 invasive breast cancers.

Interestingly, $82 \%$ of women who had tumours that contained high levels of BAG-1 had a longer survival time and were still alive 10 years after diagnosis, compared with $42 \%$ of women whose tumours contained low levels of the protein. No other biomarkers tested reached statistical significance for predicting survival (J Clin Oncol 2001, 19:992-1000).

Patients with tumours containing low levels of BAG-1 may benefit from more aggressive cancer treatments early in the course of the disease.

\section{References}

1. Turner BC, Krajewski S, Krajewska M, et al:BAG-1: A novel biomarker predicting long-term survival in early-stage breast cancer. J Clin Oncol 2001, 19:992-1000., [http://www.jco.org/cgi/content/ abstract/19/4/992]

2. Thomas Jefferson University, [http://www.tju.edu/]

This PDF file was created after publication. 